\title{
Applying Activity-Based Costing to Intercollegiate Athletics
}

\section{Heather J. Lawrence, Liz Wanless, and E. Ann Gabriel}

\begin{abstract}
Current accounting methods in intercollegiate athletics make it difficult for leaders to assess and understand the true cost of each sport team operations. Institutional and athletics leaders often make decisions concerning sport sponsorship/offerings, budget allocations, overall program operations, and review Title IX compliance based on information that may not truly capture the cost of each sport. Additionally, intercollegiate athletics reform groups and the federal government are calling for athletic departments to report more consistent, accurate, and transparent financial data. The purpose of this paper is to respond to the call for accounting reform in intercollegiate athletics via an innovative application of activity-based costing $(\mathrm{ABC})$ to one NCAA Football Bowl Subdivision (FBS) athletics department. ABC was applied to the athletic department budget report with results showing how previously established $\mathrm{ABC}$ cost drivers for intercollegiate athletics (Lawrence, Gabriel, \& Tuttle, 2010) and reallocation of expenses back to specific sports allow for a greater understanding of the cost of each sport.
\end{abstract}

Keywords: activity-based accounting, sport finance, intercollegiate athletics, NCAA

\footnotetext{
Heather J. Lawrence, PhD, is the associate dean for Graduate and Professional Programs in the College of Business and a professor in the Department of Sports Administration at Ohio University. She is also an adjunct professor at the University of Guelph (Canada). Her research interests include intercollegiate athletics finance, sport premium seating and sales, and diversity and inclusion in sport. Email: 1awrench@ohio.edu

Liz Wanless, EdD, is an assistant professor in the Department of Sports Administration at Ohio University. Her research interests include advanced analytics application to various aspects of sport organization operations, including customer relationship management, athletic fundraising, player health, and the use and diffusion of natural language processing (NLP) in the sport industry. In addition, she has conducted invited workshops explaining artificial intelligence applications and impacts for sport. Email: wanless@ohio.edu
}

E. Ann Gabriel, PhD, is an associate professor, emeritus, of the School of Accountancy at Ohio University. Prior to her career in academia, she spent almost two decades in the field of accountancy. Her research interests include the impact of market frictions on information signals in the product and capital markets as well as applications of accounting techniques to intercollegiate sports. Email: gabriele@ohio.edu 


\section{The Problem and the Innovation}

The intercollegiate athletic financial system needs a reporting overhaul. If major changes in college athletics finance are not initiated from inside college athletics, the U.S. government could step in and force change (H.R. 275, 2015; "NCAA, schools," 2014; H.R. 5100, 2014). This paper innovates intercollegiate athletic finance; it is the first to apply activity-based costing (ABC) to the reported expenses of one NCAA Division I Football Bowl Subdivision (FBS) school to explore how implementation of $\mathrm{ABC}$ would impact the understanding of sportspecific expenses.

Intercollegiate athletics' budgets have experienced unprecedented growth in recent years. The NCAA has published aggregate financial data since 2004 with results highlighting some of the most pressing financial challenges. The recent Fulks report (2017) offers key findings related to NCAA Division I FBS institutions, with only 24 of 130 FBS athletics programs reporting positive net generated revenues (non-subsidized revenue), and median total expenses have increased by over $147 \%$ since the 2004 fiscal year. In 2016, NCAA FBS institutions reported median total operating expenses $(\$ 71,689,000)$ largely outpaced median revenues ( $\$ 52,845,000$; Fulks, 2017). In an effort to address expenses outpacing revenue, university athletic departments explore cost-cutting initiatives without an accurate understanding of the costs attributable to each sport due to ineffective and potentially "misleading accounting methods and university budgetary practices" (Goff, 2000, p. 86). This has become an even more prominent issue in an era of NCAA modernization. Intense competition for premier athletic talent that encourages institutions to invest in student-athlete support such as cost of attendance, multi-year athletics aid, additional meals/snacks, mental health/general wellness support, and name, image, and likeness rule changes all illustrate NCAA evolution (McCollough \& Fenno, 2020). This is all within the context of the currently unknown full economic impact of COVID-19 (Jensen, 2020).

Adding pressure to an already stressed fiscal environment in higher education are unprecedented financial challenges resulting from the 2020 COVID-19 pandemic (Friga, 2020). Current and future institutional budget shortfalls far exceed what most schools can accommodate without drastic financial cuts (Anderson, 2020). Athletics will not go untouched by the impact of the pandemic, with $86 \%$ of NCAA Division I athletics directors expecting their institutions will require them to make financial sacrifices due to COVID-19 (LEAD1 Association \& Teamworks, 2020). Additionally, a group of conference commissioners penned a letter to the NCAA that included the statement, “... the COVID-19 pandemic and resultant economic turmoil has resulted in the direst financial crisis for higher education since at least the Great Depression" (Dinich \& Schlabach, 2020, para. 15). 
The trickle down to athletics has resulted in discontinuation of sport programs, lay-offs, furloughs, salary reductions, hiring freezes, reduction to future team travel and competition schedules, and facility construction stoppages (Anderson, 2020; Jensen, 2020). Athletics leaders are facing difficult decisions about their ability to support programs and services while also monitoring their Title IX compliance. Even in better financial times, sports teams are sometimes eliminated to ensure others are funded (Anderson, 2020; Graves, 2013; Marsh, Petersen, \& Osborne, 2016). For context, the number of eliminated college sport teams in March, April, and May 2020 was reported at 97 (Olson, 2020). Of those eliminated, 19 were in NCAA Division I, 78 from NCAA Division II and III, and 44 from NAIA institutions (Olson, 2020). This crisis and associated elimination of sport participation opportunities underscores the value of alternative accounting methods, such as ABC, that provide accurate information about the true cost of various aspects of athletics operations.

Current accounting methods that fail to accurately attribute costs to each sport increase the difficulty for leaders to make informed decisions. The University of Alabama at Birmingham (UAB) leadership experienced this when exploring a 2015 decision on sport sponsorship that eventually included three different consulting groups. UAB leadership eliminated football, bowling, and rifle based on financial data from the first outside consultant (Clements, 2015). Then, football boosters hired a second outside consultant that did not have full access to university financial information (Talty, 2015). The third, and final, outside consultant was hired to review the previous reports with access to university financial information (Talty, 2015). The decision to eliminate football based on the report from the first consultant was later reversed based on the report from the third consultant (Clements, 2015; Scarborough, 2015; Talty, 2015). Situations such as the one faced by UAB underscore why applying a standard and widely accepted accounting method such as ABC should be explored in intercollegiate athletics.

\section{Research Purpose}

This overarching purpose of this study was to apply $\mathrm{ABC}$ to one athletic department budget report. Specifically, the research questions addressed include:

1) Is there a difference in per sport operating cost between current accounting methods and when ABC is applied?

2) When examining overall operating costs of men's sports and women's sports, is there a difference between current accounting methods, Equity in Athletics Disclosure Act (EADA) reported costs, and when $\mathrm{ABC}$ is applied? 
Results show how previously established ABC cost drivers for intercollegiate athletics (Lawrence et al., 2010; Tuttle, 2009) and reallocation of expenses back to specific sports allow for a greater understanding of the cost of each sport. The outcome is a working model for consideration by athletic leaders that seek to understand the full cost of each sport in their program offerings.

\section{Literature Review}

\section{Intercollegiate Athletics Financial Challenges}

An abundance of literature exists on the financial difficulties plaguing intercollegiate athletics; however, the development of a new working accounting model remains a gap. The discussion surrounding athletic program deficits is confounded with reports that identify specific cases where "the accounting (between related-party transactions and cross-subsidies of athletic programs and universities) is more likely to understate revenues or overstate expenses (for athletic programs) than vice versa" (Rascher \& Schwarz, 2015, p. i). In their report supporting the reinstatement of football, bowling, and rifle to the UAB athletic department, Rascher and Schwartz (2015) summarized both published and unpublished cases in which athletic expenses were overestimated. Specifically, they highlighted the University of San Francisco (expenses inflated by $\$ 2.4$ million; Howell \& Rascher, 2011) and the University of Nebraska-Omaha (\$1.5 million loss should have been classified as break-even; Schwartz, 2011) as evidence of the disparities found in college athletics' financial data.

In addition, many institutions are paying millions of dollars for athletic department expenses that are inaccurately attributed to other areas on campus (Alesia, 2006; Kirk, 2014; Sperber, 2000). According to Lawrence et al. (2010), it is common to cover debt service obligations from the institution's general operating fund and/or other financial resources. It could be argued that student scholarships, loans, academic facilities, faculty salaries, and many other educational purposes suffer due to fiscal management that funnels general operating fund money to athletics. Still other perspectives highlight the instrumental role of direct and indirect benefits to the university as a result of athletic success achievement and limelight (Goff, 2000). This is also true related to revenue attribution inconsistencies such as capital project donations, privately funded coaching bonuses, and other external contributions that may not accurately appear associated with the sport they benefit (Tatos, 2019). Inconsistent accounting methods throughout college athletics, however, make fully identifying and exposing misattributions difficult. 
One of the most notable sources of literature on the difficulties plaguing intercollegiate athletics has been the Knight Commission. The Knight Commission was founded in 1989 in response to the highly visible poor state of college athletics (Knight Commission, 1991). Its original mission was to create a reform agenda to address concerns that intercollegiate athletics abuses (e.g., over-commercialization, athlete exploitation) threatened academic values and institution integrity (Knight Commission, 2001). Many quality reports from the Knight Commission (1991, 1992, 1993, 2001, 2010) were the impetus for change in policy and legislation (i.e., stronger academic standards, presidential control, increased campus engagement with intercollegiate athletics, etc.).

\section{Financial Reporting Requirements}

In addition to various university requirements associated with accounting, intercollegiate athletics departments are required to submit financial information to the U.S. Department of Education (via the EADA) as well as to the NCAA. In 2014, the Knight Commission suggested the NCAA make public each institution's data from the annual NCAA financial report on revenues and expenses to increase transparency and accountability. To date, this has not been acted upon. The EADA requires all coeducational postsecondary institutions that receive Title IV funding and that have an intercollegiate athletics program to annually report financial data to the U.S. Department of Education (U.S. Department of Education, 2005). It is commonly accepted that athletic departments are inconsistent in their accounting practices (Hodge \& Tanlu, 2009; Matheson, O’Connor, \& Herberger, 2012; Sperber, 2000; Tatos, 2019). Tatos (2019) has provided the most comprehensive analysis of advantages and disadvantages of financial reports that rely on EADA and NCAA data. There is even a cautionary note on the front page of the EADA website informing readers that because of accounting discrepancies, "valid comparisons of athletics data are possible only with study and analysis of the conditions affecting each institution" (U.S. Department of Education, n.d., para. 2). Areas of variation are most likely found in how institutions report non-gender and non-sport specific allocations in addition to the previously mentioned misattribution of private revenue sources and expense categories absorbed by the institution. Rich Franchak, senior associate athletic director/chief financial officer for the Department of Athletics at Ohio University, explains:

The not-allocated-by-gender/sport category used in NCAA and the Equity in Athletics Disclosure Act (EADA) college athletics financial reporting is how colleges account for indirect expenses they do not assign to specific sports. Many expenses incurred by college athletic programs are not directly attributable to a specific team or gender. 
Support services such as academic advising, athletic training, and NCAA compliance are often centrally managed and designed to serve all teams and student-athletes. Distributing these indirect expenses to specific teams is not as straightforward as direct costs, and there is no clear definition as to what indirect costs should be allocated nor is there a standard method for how to allocate them. While distributing more indirect expenses to specific sports won't affect the bottom line for athletic department financial reporting, a thoughtful allocation of these expenses can provide a more accurate accounting of the total resources expended for each team. (personal communication, January 31, 2019)

The NCAA also requires financial reporting that is more standardized than EADA data, including data on expenses and revenues, salary and benefits, capital expenditures, value of endowments, value of pledges, and fiscal year-end fund balance (NCAA, 2014). The NCAA data is more consistent in its reporting requirements compared to EADA, based upon NCAA-published agreed-upon procedures for reporting (NCAA, 2018). However, only aggregate data are publicly available, making the reports of no value in individual institutional analysis. Along with academics (e.g., McEvoy, Morse, \& Shapiro, 2013; Tatos, 2019), NCAA president Mark Emmert has acknowledged the lack of fiscal transparency and barriers to greater transparency, saying, "The differences in reporting obligations between public and private institutions were a principal roadblock to greater transparency" (“NCAA, schools," 2014, para. 8).

In addition to the lack of financial transparency, consistency in reporting between institutions is also an issue (McEvoy et al., 2013; Tatos, 2019). In response to the question about why each school tracks financial data in so many different ways, Kirk (2014) wrote,

Athletic departments are trying to walk a rhetorical tightrope. They want to hide their profits to make it easier to keep them away from other would-be claimants. They also want to avoid looking so poor that other stakeholders within academia use sports' apparent poverty to strip them of power. Rhetoric that turns a price into a cost, and a transfer of profit into a loss of money, helps play a role in confusing things enough that the moment in the magic trick where the profit is moved from one pocket to the other gets obscured. (para. 12)

Additional authors echo the overestimation of expenses in the athletic department accounting process (Goff, 2000; Rascher \& Schwartz, 2015). For example, the cost of staff positions such as academic advisors may be distributed to all sports programs, allocated at a higher percentage to the sports that benefit and use the resource more, or not allocated at all (Thelin, 2000). Other examples of varying accounting by institution range from the treatment of purchases such as 
athletic tape used by multiple teams to larger items such as utility costs and facility depreciation. Similar inconsistencies, even within the same conference, can also be found in the recording of scholarships and coaches' salaries (Zimbalist, 2003). In order to understand, analyze, and assess the financial state of intercollegiate athletics, a consistent set of accounting practices needs to be established.

\section{Government Intervention}

In response to issues such as those previously mentioned, the federal government is considering two proposals related to intercollegiate athletics. The first, H.R. 5100, Standardization of Collegiate Oversight of Revenue and Expenditures Act (SCORE), seeks to revamp NCAA financial reporting to create a better understanding of intercollegiate athletics funding ("NCAA, schools," 2014; H.R. 5100, 2014). Specifically, David Price (D-NC), the sponsor of H.R. 5100, suggests, "[c]ollege sports are one of America's proudest traditions, but the current system isn't working equally well for all participants ... Constructive, realistic reforms depend on a clear understanding of the financial pressures and benefits of intercollegiate athletics" ("NCAA, schools," 2014, para. 3).

The second proposal, H.R. 275, also known as the National Collegiate Athletics Accountability Act, or NCAA Act, seeks to establish the Congressional Commission on Intercollegiate Athletics, which will examine a variety of issues (e.g., interaction of athletics and academics, athletics financing, recruitment and retention of student-athletes, oversight and governance, health and safety, and due process) in intercollegiate athletics (H.R. 275, 2015). B. David Ridpath, co-author of H.R. 275, notes the financial elements of the bill include, "the Commission having a role in review and consideration of sources of revenue including institutional subsidies, expenditures including compliance with Title IX and coaching salaries, the ability of institutions to finance their programs, and overall fiscal transparency" (personal communication, September 1, 2019).

\section{Activity-Based Costing}

There is extensive theoretical and applied literature relating to activitybased costing (e.g., Amhed et al., 2011; Balakrishnan et al., 2012; Cardinaels, Roodhooft, \& Warlop, 2004; Cooper \& Kaplan, 1988; Dimitropoulos, 2007; Jorgensen \& Edwards, 1998; Mansor et al., 2012; Smith, Burt, \& Gentile, 2019; Stratton, Desroches, Lawson, \& Hatch, 2009). Although ABC was created to improve cost-allocation processes for large manufacturing firms, it has been applied to many different industries, including airlines (Banker \& Johnston, 1993), universities (Granof, Platt, \& Vaysman, 2000), and e-retailing (Zeller, 
2000). However, the method has not yet been applied to intercollegiate athletics. ${ }^{1}$

Granof et al. (2000) conducted a case study on the accounting department of the college of business administration of a large public research university. The purpose was not to develop a complete working model of $\mathrm{ABC}$, but rather to show the feasibility and benefits of applying $\mathrm{ABC}$ in an academic environment. They found that many institutions of higher education previously had either no, or inadequate, costing systems. For these organizations, $\mathrm{ABC}$ was the first real measurement system employed, and the primary benefit of $\mathrm{ABC}$ was providing the structure needed for proper accounting. The findings most relevant to this study were that $\mathrm{ABC}$ provides useful cost information and that support services do not benefit programs uniformly (Granof et al., 2000).

In 2007, Dimitropoulos explored $\mathrm{ABC}$ within a sport context identifying 10 steps potentially needed to apply $\mathrm{ABC}$ in the sport industry. Then, Lawrence et al. (2010) developed the case and logistics for application of ABC in the intercollegiate athletics segment of the sport industry. Similar to the Granof et al. (2000) study, the purpose was to demonstrate the feasibility and benefits of applying $\mathrm{ABC}$, but neither study developed a complete working model. They identified key support activities as administration, academic advising, athletic training, compliance, development, equipment management, facilities and operations, marketing and promotions, media relations, sponsorship procurement, strength and conditioning, purchasing, and ticketing. It should be noted that not all of these activities may be in every athletic department and there may be other activities not included on this list. Also, it is becoming common for some activities such as ticketing, sponsorship, concessions, and parking to be outsourced to third-party service providers. Cost drivers identified by Lawrence et al. (2010) include personnel hours, number of tickets sold, number of events, or number of student-athletes.

Refuting the potential reality of $\mathrm{ABC}$ being adopted into intercollegiate athletics accounting practices is a study by Smith et al. (2019) that employed a survey method to collect data on intercollegiate athletics administrators' current use of $\mathrm{ABC}$ and their perspectives on accounting practices. Results indicated that the vast majority of athletic departments do not allocate indirect costs to sport teams. Reasons provided for not allocating costs included that indirect costs are allocated to a non-sport specific unit (i.e., athletic academic support, athletic training, etc.) or as part of the overall budget. Additionally, administrators noted a lack of value in allocating costs to each sport, not having a method to allocate costs, and/or that they are not required to do so (Smith et al., 2019). This study

\footnotetext{
${ }^{1}$ Reisch and Seese (2005) presented a case study in which students are instructed to use an ethical decision-making model to allocate indirect costs to men's and women's sports at a hypothetical university. The focus of the case was the ethics of allocating cost to achieve a certain objective: compliance with Title IX. Activity-based costing is not considered in the case.
} 
adds context by which researchers, including the authors of the current application, should be aware when considering the possibility of implementing ABC in intercollegiate athletics.

\section{Methods and Results}

For this study, a test NCAA Division I FBS university was selected and its detailed, audited financial statements were downloaded from the available information on the university's website. Working ABC models applied to single cases reflects accounting literature from various industries (Arnaboldi \& Lapsley, 2004; Bamber \& Hughes, 2001; Brown et al., 1999; Carducci et al., 2007; Major $\&$ Hopper, 2005). To answer the first research question focused on differences in operating costs by sport between accounting methods, previously established cost drivers (Lawrence et al., 2010) were used to apply ABC to the test institution. Then, the second research question examined reported spending on women's sport programs as compared to overall spending on men's sport programs by current accounting method, EADA reported costs, and after applying ABC.

\section{Application of $A B C$}

For the application of $\mathrm{ABC}$, the focus was on operating expenses, as those are the costs associated with the financial stability of the program. Table 1 provides the sport-specific reported expenses for the institution. The costs were included in this analysis to match the financial statements. Depreciation and amortization were excluded from analysis, as the institution's facilities are used for activities outside of athletics and there was no publicly available information to reasonably allocate the costs. ${ }^{2}$ Expenses related to camps and the sport shops/merchandise were excluded, as they are self-contained, separate reporting entities and were not team-specific for this university. ${ }^{3}$ Also excluded were development expenses, as there was no publicly available information to reasonably allocate the costs. Additionally, the inclusion of development staff is complicated, as the organizational structures for athletic fundraising staff can involve a dual-report structure such as is the case for the institution used in this study. ${ }^{4}$ Scholarships were excluded, as NCAA policy mandates scholarship limits and distribution by

\footnotetext{
${ }^{2}$ Costs associated with institutional elective participation in cost-of-attendance support, on-campus versus off-campus housing expenses, and future permissive expenses as the NCAA evolves should be considered in future financial analyses.

${ }^{3}$ It should be noted that camps/clinic operations can vary greatly by institution and can range from a coach/team-specific run camp, to third-party involvement, to a broader university initiative.

${ }^{4}$ Often, development professionals' efforts are split between fundraising for non-athletic university causes and fundraising for athletics, so nuances such as this are critical to have a clear understanding of the situation.
} 
sport, and Title IX addresses how to measure scholarship ratios for compliance. Table 2 provides a complete breakdown of the total expenses.

The main expense categories to be allocated to the sports were general

Table 1. Sport-Specific Reported Expenses of Sample Division I FBS University (US\$)

\begin{tabular}{lrcr}
\hline & Men's Expenses & $\begin{array}{c}\text { Women's } \\
\text { Expenses }\end{array}$ & Total \\
\hline Salaries, benefits, and bonuses & $12,868,456$ & $4,519,819$ & $17,388,274$ \\
Travel & $3,745,963$ & $2,417,603$ & $6,163,565$ \\
Contract guarantees & $2,964,750$ & 101,640 & $3,066,390$ \\
Event operations & 5,021715 & 533,446 & $5,555,160$ \\
Officials & 479,238 & 251,278 & 730,516 \\
Recruiting & $1,061,163$ & 504,449 & $1,565,611$ \\
Equipment & $1,337,445$ & 799,270 & $2,136,714$ \\
Band & 771,074 & 80,000 & 851,074 \\
Other & $2,559,824$ & 375,257 & $2,935,080$ \\
\hline Total expenses & $30,809,625$ & $9,582,759$ & $40,392,384$ \\
\hline
\end{tabular}

Table 2. Reported Expenses of Athletic Department of Sample University (US\$)

\begin{tabular}{lr}
\hline Expense Category & Amount \\
\hline Operating costs included in the analysis & \\
General and administrative & $25,957,609$ \\
Support services & $11,691,442$ \\
Total allocated costs & $37,649,051$ \\
Sport-specific categories other than scholarships & $40,392,384$ \\
Total operating costs & $78,041,435$ \\
Other expenses not included in analysis & \\
Scholarships & $10,824,910$ \\
Development & $2,610,004$ \\
Depreciation & $8,496,719$ \\
Sports shop & $1,302,294$ \\
Camps & $2,164,161$ \\
Total expenses reported by the university & $103,439,523$ \\
\hline
\end{tabular}


and administrative, and support services. General and administrative expenses included administration, compliance, facility and operations, and ticketing. Support services included academic advising, athletic training, equipment management, marketing and promotions, media relations, and strength and conditioning. Detailed information on these expenses was found in the notes and supplemental information to the financial statements. All information was manually entered on a Microsoft Excel spreadsheet. Table 3 provides a complete breakdown of the operating expenses to be allocated to the sports using $\mathrm{ABC}$.

Cost drivers were identified for each expense category. Cost drivers were assigned based on the particular department and linking a measurable unit to the activity. Cost drivers used were established by Lawrence et al. (2010), including number of student-athletes, number of employees related to the sports program, and ticketed attendance divided by the number of games. ${ }^{5}$ The number of student-athletes, organizational chart, and ticketed attendance were obtained from the athletics website. The cost drivers used to allocate each expense category is found in Table 4 . Table 5 presents the number and percentage of the cost drivers attributable to each sport.

The final step was to allocate the expense associated with each activity to the sports as presented in Table $6 .{ }^{6}$ In the process of applying ABC by sport, it was found that football has the most student-athletes (125, or 19\%), the largest attendance per game $(87,597$, or $75 \%$ ), and the most employees directly related to the sport (18, or $12 \%)$. Consequently, $29 \%$ of the general and administrative, and support services were allocated to football. Women represent $56 \%$ of non-football student-athletes and $60 \%$ of the non-football employees were related to women's sports. Accordingly, women's sports as a whole were allocated $41 \%$ of the general and administrative, and support services, while the remaining men's sports were allocated $30 \%$ of those expenses. The total ABC expense by sport is presented in Table 7.

\footnotetext{
${ }^{5}$ Some may question the characterization of our proposed system as an ABC system. Due to limited available information, our cost drivers may not be as closely linked to activities as one would usually find in an $\mathrm{ABC}$ system. Internal information is likely needed to implement a true ABC system. For example, the number of hours of academic advising and athletic training provided to specific student-athletes could be aggregated by sport to provide a more accurate cost of those activities. However, we believe our proposed system improves the cost information provided to administrators.

${ }^{6}$ Women's administration expenses were allocated to the women's sports based on the employees attributable to a given women's sport as a percentage of all employees of women's sports. For example, women's basketball was allocated $14 \%$ of the women's administration expenses.
} 
Table 3. Expenses of Athletic Department of Sample University Allocated to ABC (US\$)

\begin{tabular}{|c|c|}
\hline Category & Amount \\
\hline \multicolumn{2}{|l|}{ General and administrative } \\
\hline \multicolumn{2}{|l|}{ Administration } \\
\hline Administrative & $6,350,977$ \\
\hline Human resources & 864,993 \\
\hline Employee benefits & $2,244,672$ \\
\hline Utilities, insurance, and services & $5,137,508$ \\
\hline Information technology & $1,610,707$ \\
\hline Women's administration & 494,035 \\
\hline Purchasing & 599,107 \\
\hline Licensing & 289,301 \\
\hline Golf course & $1,430,955$ \\
\hline Outside events & 23,248 \\
\hline Total administration & $19,045,503$ \\
\hline \multicolumn{2}{|l|}{ Facility and operations } \\
\hline Operations & 508,210 \\
\hline Maintenance & $3,046,394$ \\
\hline Aviation & 838,959 \\
\hline Total facility and operations & $4,393,563$ \\
\hline Compliance & 442,944 \\
\hline Ticketing & $2,075,599$ \\
\hline Total general and administrative & $25,957,609$ \\
\hline \multicolumn{2}{|l|}{ Support services } \\
\hline Academic advising & $2,188,952$ \\
\hline Athletic training & $3,544,228$ \\
\hline Equipment management & 518,365 \\
\hline Marketing \& promotions & $2,182,613$ \\
\hline Media relations & $1,467,761$ \\
\hline \multicolumn{2}{|l|}{ Strength and conditioning } \\
\hline Football video expenses & 515,441 \\
\hline Other sports video expenses & 240,684 \\
\hline Strength \& conditioning & $1,033,398$ \\
\hline Total strength \& conditioning & $1,789,523$ \\
\hline Total support services & $11,691,442$ \\
\hline Total $A B C$ categories & $37,649,051$ \\
\hline
\end{tabular}


Table 4. Cost Drivers Allocated by Expense Category

\begin{tabular}{ll}
\hline Category & Cost Drivers \\
\hline Administration & Number of employees \\
Academic advising & Number of student-athletes \\
Athletic training & Number of student-athletes \\
Compliance & Number of student-athletes \\
Equipment & Number of student-athletes \\
Facility and operations & Total attendance / number of games \\
Marketing and promotions & Total attendance / number of games \\
Media relations & Total attendance / number of games \\
Strength and conditioning & Sport-identifiable costs \\
Ticketing & Number of student-athletes \\
\hline
\end{tabular}


Table 5. Cost Drivers Attributable to Men's and Women's Sports by Number and Percentage

\begin{tabular}{|c|c|c|c|c|c|c|c|}
\hline & \multicolumn{2}{|c|}{ Student-Athletes } & \multicolumn{2}{|c|}{ Games } & \multicolumn{3}{|c|}{ Employment } \\
\hline & Number in sport & $\begin{array}{l}\text { Percentage of } \\
\text { all student- } \\
\text { athletes }\end{array}$ & $\begin{array}{l}\text { Average } \\
\text { attendance per } \\
\text { game }\end{array}$ & $\begin{array}{l}\text { Percentage of } \\
\text { all tickets sold }\end{array}$ & $\begin{array}{l}\text { Salaries } \\
\text { attributable to } \\
\text { sport }\end{array}$ & $\begin{array}{l}\text { Employees } \\
\text { attributable to } \\
\text { sport }\end{array}$ & $\begin{array}{l}\text { Percentage } \\
\text { of athletics } \\
\text { employees }\end{array}$ \\
\hline \multicolumn{8}{|l|}{ Men's sports } \\
\hline Football & 125 & $19.00 \%$ & 87,597 & $74.71 \%$ & $\$ 3,714,135$ & 18 & $12.00 \%$ \\
\hline Basketball & 14 & $2.00 \%$ & 8,914 & $7.83 \%$ & $\$ 897,114$ & 10 & $7.00 \%$ \\
\hline Baseball & 34 & $5.00 \%$ & 3,935 & $3.46 \%$ & $\$ 507,946$ & 10 & $7.00 \%$ \\
\hline Golf & 12 & $2.00 \%$ & $\mathrm{n} / \mathrm{a}$ & $0.25 \%$ & $\$ 178,889$ & 9 & $6.00 \%$ \\
\hline Tennis & 13 & $2.00 \%$ & $\mathrm{n} / \mathrm{a}$ & $0.25 \%$ & $\$ 176,637$ & 3 & $2.00 \%$ \\
\hline Track \& field/cross country & 112 & $17.00 \%$ & $\mathrm{n} / \mathrm{a}$ & $0.25 \%$ & $\$ 292,159$ & 11 & $7.00 \%$ \\
\hline Swimming \& diving & 44 & $7.00 \%$ & $\mathrm{n} / \mathrm{a}$ & $0.25 \%$ & $\$ 256,641$ & 9 & $6.00 \%$ \\
\hline Total & 354 & $54.38 \%$ & 100,446 & $87.00 \%$ & $\$ 6,023,521$ & 70 & $47.62 \%$ \\
\hline \multicolumn{8}{|l|}{ Women's sports } \\
\hline Basketball & 14 & $2.00 \%$ & 1,433 & $1.26 \%$ & $\$ 668,581$ & 11 & $7.00 \%$ \\
\hline Golf & 8 & $1.00 \%$ & $\mathrm{n} / \mathrm{a}$ & $0.25 \%$ & $\$ 133,390$ & 2 & $1.00 \%$ \\
\hline Gymnastics & 20 & $3.00 \%$ & 6,127 & $5.38 \%$ & $\$ 353,936$ & 4 & $3.00 \%$ \\
\hline Soccer & 32 & $5.00 \%$ & 1,999 & $1.76 \%$ & $\$ 274,698$ & 8 & $5.00 \%$ \\
\hline Softball & 21 & $3.00 \%$ & 1,161 & $1.02 \%$ & $\$ 310,463$ & 10 & $7.00 \%$ \\
\hline Swimming \& diving & 33 & $5.00 \%$ & $\mathrm{n} / \mathrm{a}$ & $0.25 \%$ & $\$ 256,641$ & 9 & $6.00 \%$ \\
\hline Tennis & 8 & $1.00 \%$ & $\mathrm{n} / \mathrm{a}$ & $0.25 \%$ & $\$ 270,972$ & 4 & $3.00 \%$ \\
\hline Track \& field/cross country & 120 & $18.00 \%$ & $\mathrm{n} / \mathrm{a}$ & $0.25 \%$ & $\$ 292,159$ & 11 & $7.00 \%$ \\
\hline Volleyball & 16 & $2.00 \%$ & 2,660 & $2.34 \%$ & $\$ 371,897$ & 8 & $5.00 \%$ \\
\hline Lacrosse & 25 & $4.00 \%$ & $\mathrm{n} / \mathrm{a}$ & $0.25 \%$ & $\$ 250,297$ & 10 & $7.00 \%$ \\
\hline Total & 297 & $45.62 \%$ & 13,380 & $13.00 \%$ & $\$ 3,183,034$ & 77 & $52.38 \%$ \\
\hline Combined totals & 651 & $100.00 \%$ & 113,826 & $100.00 \%$ & $\$ 9,206,555$ & 147 & $100.00 \%$ \\
\hline
\end{tabular}


Table 6. Expenses Allocated by Sport (US\$)

\begin{tabular}{|c|c|c|c|c|c|c|c|c|c|c|c|c|}
\hline & Administration & $\begin{array}{l}\text { Academic } \\
\text { advising }\end{array}$ & $\begin{array}{l}\text { Athletic } \\
\text { training }\end{array}$ & Compliance & Equipment & $\begin{array}{c}\text { Facility \& } \\
\text { operations }\end{array}$ & $\begin{array}{l}\text { Marketing \& } \\
\text { promotions }\end{array}$ & Media relations & $\begin{array}{l}\text { Strength \& } \\
\text { conditioning }\end{array}$ & Ticketing & Total & $\begin{array}{l}\text { Percentage of } \\
\text { total }\end{array}$ \\
\hline \multicolumn{13}{|l|}{ Men's sports } \\
\hline Football & $2,332,102$ & 420,306 & 680,535 & 85,051 & 302,518 & $3,282,303$ & $1,073,795$ & 963,159 & 343,610 & $1,550,620$ & $11,033,999$ & $29 \%$ \\
\hline Basketball & $1,295,612$ & 47,074 & 76,220 & 9,526 & 5,745 & 344,072 & 271,589 & 137,472 & 38,484 & 162,546 & $2,388,340$ & $6 \%$ \\
\hline Baseball & $1,295,612$ & 114,323 & 185,106 & 23,134 & 13,952 & 151,887 & 150,212 & 69,047 & 93,462 & 71,754 & $2,168,489$ & $6 \%$ \\
\hline Golf & $1,166,051$ & 40,349 & 65,331 & 8,165 & 4,924 & 10,984 & 5,202 & 9,407 & 32,987 & 5,189 & $1,348,590$ & $4 \%$ \\
\hline Tennis & 388,684 & 43,712 & 70,776 & 8,845 & 5,335 & 10,984 & 13,847 & 8,154 & 35,735 & 5,189 & 591,261 & $2 \%$ \\
\hline $\begin{array}{l}\text { Track and field/ } \\
\text { cross country }\end{array}$ & $1,425,174$ & 376,594 & 609,760 & 76,205 & 45,960 & 10,984 & 15,171 & 7,878 & 307,875 & 5,189 & $2,880,789$ & $8 \%$ \\
\hline $\begin{array}{l}\text { Swimming \& } \\
\text { diving }\end{array}$ & $1,166,051$ & 147,948 & 239,548 & 29,938 & 18,056 & 10,984 & 7,618 & 5,214 & 120,951 & 5,189 & $1,751,497$ & $5 \%$ \\
\hline Total & $9,069,287$ & $1,190,306$ & 1,927,276 & 240,864 & 396,489 & $3,822,197$ & $1,537,434$ & $1,200,332$ & 973,105 & $1,805,675$ & $22,162,966$ & $59 \%$ \\
\hline \multicolumn{13}{|l|}{ Women's sports } \\
\hline Basketball & $1,425,174$ & 47,074 & 76,220 & 9,526 & 5,745 & 55,304 & 182,405 & 41,346 & 38,484 & 26,126 & $1,907,404$ & $5 \%$ \\
\hline Golf & 259,122 & 26,900 & 43,554 & 5,443 & 3,283 & 10,984 & 5,202 & 9,257 & 21,991 & 5,189 & 390,926 & $1 \%$ \\
\hline Gymnastics & 518,245 & 67,249 & 108,886 & 13,608 & 8,207 & 236,496 & 129,148 & 79,857 & 54,978 & 111,725 & $1,328,399$ & $4 \%$ \\
\hline Soccer & $1,036,490$ & 107,598 & 174,217 & 21,773 & 13,131 & 77,159 & 86,870 & 34,386 & 87,964 & 36,452 & $1,676,041$ & $4 \%$ \\
\hline Softball & $1,295,612$ & 70,611 & 114,330 & 14,289 & 8,617 & 44,813 & 66,642 & 21,825 & 57,727 & 21,171 & $1,715,637$ & $5 \%$ \\
\hline $\begin{array}{l}\text { Swimming \& } \\
\text { diving }\end{array}$ & 1,166,051 & 110,961 & 179,661 & 22,453 & 13,542 & 10,984 & 7,618 & 5,214 & 90,713 & 5,189 & 1,612,387 & $4 \%$ \\
\hline Tennis & 518,245 & 26,900 & 43,554 & 5,443 & 3,283 & 10,984 & 15,178 & 9,468 & 21,991 & 5,189 & 660,235 & $2 \%$ \\
\hline Track and field & $1,425,174$ & 403,493 & 653,314 & 81,649 & 49,243 & 10,984 & 8,651 & 7,435 & 329,866 & 5,189 & $2,974,997$ & $8 \%$ \\
\hline Volleyball & $1,036,490$ & 53,799 & 87,109 & 10,886 & 6,566 & 102,673 & 101,901 & 42,592 & 43,982 & 48,505 & $1,534,504$ & $4 \%$ \\
\hline Lacrosse & $1,295,612$ & 84,061 & 136,107 & 17,010 & 10,259 & 10,984 & 41,563 & 16,047 & 68,722 & 5,189 & $1,685,555$ & $4 \%$ \\
\hline Total & $9,976,216$ & 998,646 & $1,616,952$ & 202,080 & 121,876 & 571,366 & 645,179 & 267,429 & 816,418 & 269,924 & $15,486,085$ & $41 \%$ \\
\hline Combined totals & $19,045,503$ & $2,188,952$ & $3,544,228$ & 442,944 & 518,365 & 4,393,563 & $2,182,613$ & $1,467,761$ & $1,789,523$ & $2,075,599$ & $\$ 37,649,051$ & $100 \%$ \\
\hline
\end{tabular}


Table 7. Total ABC Expense by Sport (US\$)

\begin{tabular}{|c|c|c|c|}
\hline & $\begin{array}{l}\text { Sport-Specific } \\
\text { Categories }\end{array}$ & $\begin{array}{c}\text { ABC Additional Cost } \\
\text { as Developed in } \\
\text { Table } 6\end{array}$ & Total ABC Cost \\
\hline \multicolumn{4}{|l|}{ Men's teams } \\
\hline Football & $18,542,214$ & $11,033,999$ & $29,576,213$ \\
\hline Basketball & $7,487,970$ & $2,388,340$ & $9,876,310$ \\
\hline Baseball & $1,997,081$ & $2,168,489$ & $4,165,570$ \\
\hline Golf & 394,560 & $1,348,590$ & $1,743,150$ \\
\hline Tennis & 537,504 & 591,261 & $1,128,765$ \\
\hline \multicolumn{4}{|l|}{ Track and field/ } \\
\hline Cross country & $1,135,211$ & $2,880,789$ & $4,016,000$ \\
\hline Swimming \& diving & 715,085 & $1,751,497$ & $2,466,582$ \\
\hline Total men's teams & $30,809,625$ & $22,162,966$ & $52,972,591$ \\
\hline \multicolumn{4}{|l|}{ Women's teams } \\
\hline Basketball & $2,167,810$ & $1,907,404$ & $4,075,214$ \\
\hline Golf & 325,379 & 390,926 & 716,305 \\
\hline Gymnastics & 966,721 & $1,328,399$ & $2,295,120$ \\
\hline Soccer & 800,005 & $1,676,041$ & $2,476,046$ \\
\hline Softball & 817,141 & $1,715,637$ & $2,532,778$ \\
\hline Swimming \& diving & 715,086 & $1,612,387$ & $2,327,472$ \\
\hline Tennis & 627,151 & 660,235 & $1,287,386$ \\
\hline \multicolumn{4}{|l|}{ Track and field/ } \\
\hline cross country & $1,135,211$ & $2,974,997$ & $4,110,208$ \\
\hline Volleyball & $1,216,744$ & $1,534,504$ & $2,751,248$ \\
\hline Lacrosse & 811,511 & $1,685,555$ & $2,497,066$ \\
\hline Total women's teams & $9,582,759$ & $15,486,085$ & $25,068,844$ \\
\hline $\begin{array}{l}\text { Total as presented in } \\
\text { Table } 2\end{array}$ & $40,392,384$ & $37,649,051$ & $78,041,435$ \\
\hline
\end{tabular}




\section{Gender Equity and Title IX}

To respond to the second research question, "When examining overall operating costs of men's sports and women's sports, is there a difference between current accounting methods, Equity in Athletics Disclosure Act (EADA) reported costs, and when $\mathrm{ABC}$ is applied?", EADA financial data for the test institution was downloaded. Table 8 provides a comparison of costs as established by ABC, reported under the EADA guidelines, and costs reported by the institution. Unallocated costs were $\$ 55.08$ million and $\$ 37.65$ million under the EADA and institution reports, respectively. The unallocated costs represent $49.6 \%$ of the EADA reported costs and $48.2 \%$ of institutional reported costs. ABC eliminates unallocated costs and provides a more accurate picture of the cost of each sport.

Table 8. Comparison Costs by Report Type (US\$)

\begin{tabular}{lrrr}
\hline & Total ABC cost & EADA cost & $\begin{array}{r}\text { Institution- } \\
\text { reported cost }\end{array}$ \\
\hline Men's teams & & & \\
Football & $29,576,213$ & $23,045,846$ & $18,542,214$ \\
Basketball & $9,876,310$ & $8,474,783$ & $7,487,970$ \\
Baseball & $4,165,570$ & $2,775,898$ & $1,997,081$ \\
Golf & $1,743,150$ & 601,938 & 394,560 \\
Tennis & $1,128,765$ & $1,131,230$ & 537,504 \\
Track and field/cross country & $4,016,000$ & $1,725,668$ & $1,135,211$ \\
Swimming \& diving & $2,466,582$ & $1,428,349$ & 715,085 \\
Women's teams & & & \\
Basketball & $4,075,214$ & $3,102,132$ & $2,167,810$ \\
Golf & 716,305 & 509,516 & 325,379 \\
Gymnastics & $2,295,120$ & $1,749,841$ & 966,721 \\
Soccer & $2,476,046$ & $1,637,821$ & 800,005 \\
Softball & $2,532,778$ & $1,575,352$ & 817,141 \\
Swimming \& diving & $2,327,472$ & $1,434,439$ & 715,085 \\
Tennis & $1,287,386$ & $1,092,579$ & 627,151 \\
Track and field/cross country & $4,110,208$ & $1,920,770$ & $1,135,211$ \\
Volleyball & $2,751,248$ & $2,241,480$ & $1,216,744$ \\
Lacrosse & $2,497,066$ & $1,484,287$ & 811,511 \\
Unallocated expense & & $55,075,382$ & $37,649,051$ \\
Total & - & $111,007,311$ & $78,041,435$ \\
\hline
\end{tabular}

Note. EADA costs may include expenses excluded for purposes of this study. However, due to the lack of detail, specific amounts for these costs cannot be identified and excluded. 
From a total, macro perspective, spending on women's sports as measured by direct costs represent only $24 \%$ of total expenditures, while spending on women's sports as measured by ABC represents $32 \%$ of total expenditures. In this case, the data provide evidence that women's sports are proportionally more expensive when using $\mathrm{ABC}$ as compared to current accounting methods. Therefore, from a gender equity perspective, $\mathrm{ABC}$ for this institution shows more equity by gender and a more favorable position for the institution related to Title IX compliance even without a statistical difference. The results indicate EADA and institutional reports do not address requests from the Knight Commission or the federal government for more data, better data, and more transparent data.

\section{Discussion}

This paper is the first to apply activity-based costing to the reported expenses of one NCAA Division I FBS school to provide a clearer picture of sport expenses in comparison with current financial reporting requirements and, as a result, to provide insight for Title IX compliance. The results of the ABC working model for one institution innovate the practice of intercollegiate athletics accounting reform by:

- demonstrating how $\mathrm{ABC}$ application attributes cost to each sport through using established cost drivers, allocating cost drivers to expense categories, and attributing the expense to the corresponding sport;

- illustrating the extent of the deficiencies in current accounting methods (EADA guidelines and institutional reporting) by reassigning unallocated costs;

- establishing increased transparency in financial reporting after accurately transferring unallocated costs appropriately to each sport;

- showing how accurately attributing cost provides insight for gender equity considerations and Title IX compliance;

- providing a template for a more accurate financial reporting system that better informs institution leaders as difficult financial decisions are made; and

- producing a model for a more accurate cost reporting system - the groundwork for additional and necessary NCAA member institution athletics program financial reforms.

If all institutions adopted a uniform accounting method, such as $\mathrm{ABC}$, the result would be a set of more accurate, consistent, and transparent financial reporting data. This adoption could come about via requirements in EADA reporting structure, additional federal interventions, or by conference or NCAA mandates. 
If such a consistent financial reporting practice were to begin, academics and athletics leaders alike would be better able to assess the status of intercollegiate athletics finance across all NCAA divisions and all institutions. As evidenced by the work of Smith et al. (2019), indirect cost allocation is not part of current practices in intercollegiate athletics accounting and athletic leaders are not aware of the benefits of methods such as ABC, so the shift to ABC would be substantial in practice. However, if a governing body such as the NCAA established standard cost drivers and methods, in addition to requiring $\mathrm{ABC}$ in external reporting, all institutions would be examined under the same guidelines.

Figure 1 presents a comparison of the percentage of cost attributable to each sport as reported by the institution and using ABC. Data for this comparison can be found throughout the paper, but notably in Table 1, Table 7, and Table 8. For institution reported costs, the sport cost (Table 8) is divided by the institution's total reported sport costs of $\$ 40,392,384$ (Table 1). For ABC, the sport cost after applying ABC (Table 8 derived from Table 7) is divided by the total of the sport specific costs of $\$ 78,041,435$ (Table 8 derived from Table 7). Although football and men's basketball incur the most expenses, under ABC, the percentage allocated to football falls from $46 \%$ of costs to $38 \%$. Similarly, the percentage for men's basketball falls from $19 \%$ to $13 \%$. Most other sports show an increase in the percentage of cost as is typical of many $\mathrm{ABC}$ implementations.

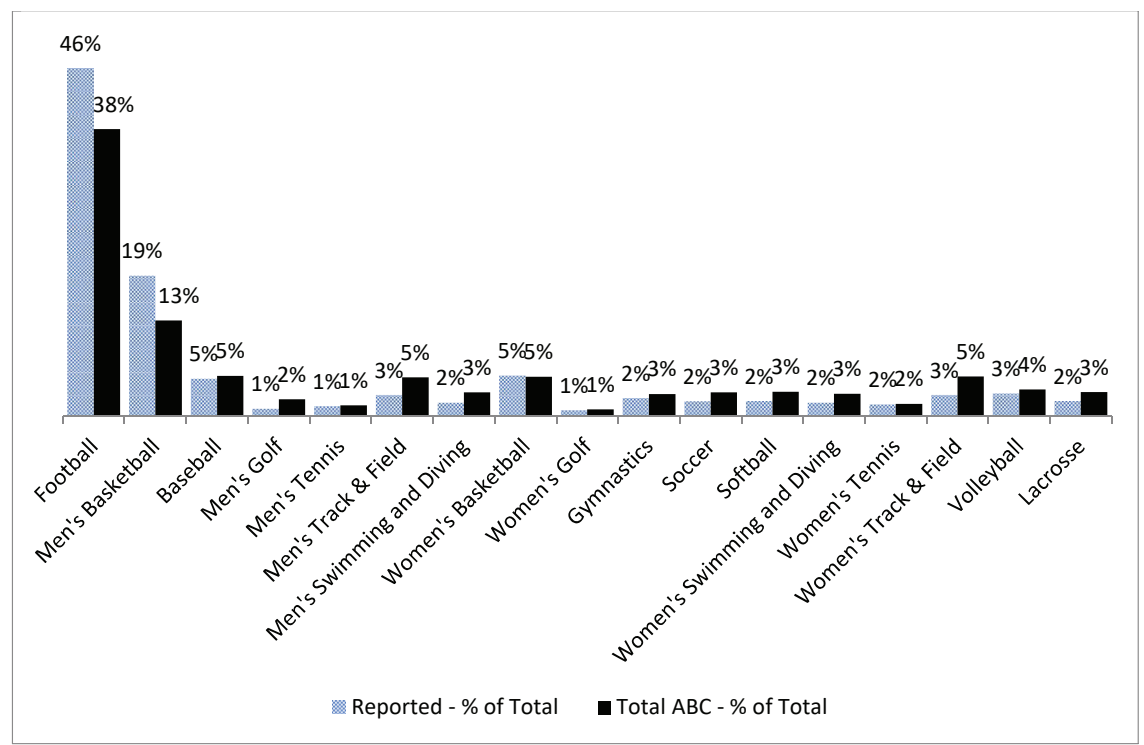

Figure 1. Comparison of institution reported cost and $A B C$ cost as the percentage of total cost. 
Within the framework of Title IX compliance, the results allow for a critical analysis of a more accurate operational cost of each sport and overall by gender. Between the 1988-89 and 2017-18 academic years, there has been a net loss of 323 NCAA Division I men's sport teams (NCAA, n.d.). The loss of men's sport teams has frequently been associated with an institution's effort to become compliant with Title IX. Other than athletic scholarships, Title IX does not specify financial thresholds for equitable spending on men's and women' sports. The remaining requirement includes sport equitable treatment and benefits for male and female student-athletes. According to the NCAA, "This takes into consideration the variables of equipment costs and other things that may be unique to a particular sport, but the quality of equipment and other benefits provided both genders overall should be equitable (NCAA, n.d. p. 6).

Applying $\mathrm{ABC}$ to currently unallocated costs can be beneficial to an institution's understanding of its resource allocation to the 11 areas of support that are identified as part of Title IX treatment and benefits (i.e., equipment and supplies; scheduling of games and practice times; travel and daily allowance/per diem; access to tutoring; coaching; locker rooms, practice and competitive facilities; medical and training facilities and services; publicity and promotions; support services; and recruitment; NCAA, n.d.).

Using ABC as sole or primary evidence of Title IX compliance is not the intent. This is merely one more piece of data from which a case of compliance can be built. For example, when individual sports fielding both men's and women's teams are considered, expenditure percentages should be similar. As can be seen in Table 8 and Figure 1, the percentages of costs for swimming and diving and track and field are the same for men's and women's teams. Men's golf incurs $2 \%$ of costs while women's golf incurs $1 \%$ of costs. However, the reverse occurs in men's and women's tennis, with women incurring $2 \%$ of the costs and men $1 \%$. There is greater disparity between men's baseball (5\%) and women's softball (3\%). Of note in Table 8 is the comparison of men's and women's basketball that shows greater budget equity between men's and women's basketball using $\mathrm{ABC}$ in comparison with other accounting methods. This suggests that this university should investigate what is driving the differences given similarities of roster size and coaching staffs. ${ }^{7}$ Therefore, depending on the results of the application of $\mathrm{ABC}$ by an institution, the data could enhance or detract from an institution's argument about gender equity and Title IX compliance.

\footnotetext{
${ }^{7}$ This result could be driven by the use of attendance as the cost driver for media and facilities expenses. This is an example of how internal data may lead to better cost drivers for these expenses. It could also suggest a need to take steps to increase attendance at women's basketball games.
} 


\section{Limitations and Future Directions}

Applying $\mathrm{ABC}$ to one organization, such as the institution under study in this research, is a common method in the $\mathrm{ABC}$ literature (i.e., Arnaboldi \& Lapsley, 2004; Bamber \& Hughes, 2001; Brown et al., 1999; Carducci et al., 2007; Major \& Hopper, 2005). However, it is also a recognized limitation in understanding $\mathrm{ABC}$ within any business segment. The organization, or business type, has to design an $\mathrm{ABC}$ system that best fits its needs and circumstances. This application of $A B C$ was limited to publicly available information at one institution. Should intercollegiate athletics overall or individual athletics departments implement $\mathrm{ABC}$, the NCAA could lead the effort to develop more precise cost drivers to be used and tested. For example, academic advising could be allocated by hours of tutoring, strength and conditioning or training could be allocated by the hours working with a student-athlete, and athletic fundraising professionals that split time between university and athletic program initiatives could be allocated by hours spent supporting the athletic program. Ideally, the cost drivers should be uniform across all adopters of $\mathrm{ABC}$ to realize the full benefits of comparability.

Academicians and practitioners have ample opportunity to build upon this line of research in the future. Replicating this study with a larger sample would provide more robust results. Additionally, comparisons by NCAA Division I type (FBS, FCS, and non-football) as well as NCAA Division II, III, and by athletic conference all remain unexplored. Including permissible expenses such as cost-of-attendance, difference in meal and housing stipends based on on- or off-campus living, and ever-evolving allowable expenses should also be analyzed.

Finally, it is likely that intercollegiate athletics as a subset of the sport business industry will experience a major transformation in the near future. In 2020, there continue to be indications of federal government intervention with respect to college athletics name, image, and likeness (McCollough \& Fenno, 2020) in addition to the still unknown (as of June 2020) economic impact of COVID-19 on college sport (Anderson, 2020; Jensen, 2020). These environmental forces will provide academicians new contextual elements critical to any examination of accounting methods or finances in intercollegiate athletics.

\section{Conclusion}

Intercollegiate athletic reform groups have expressed concern, and government entities are poised to intervene, in intercollegiate athletic finances (e.g., H.R. 275, 2015; H.R. 5100, 2014; Knight Commission, 2011, 2014; The Drake Group, 2015; U.S. Department of Education Office for Civil Rights, 2005). Enter ABC as an intercollegiate athletic finance innovation to answer the call for more consistent, accurate, and transparent financial data. By applying $\mathrm{ABC}$ to athletics financial 
analysis, university leaders become armed with more accurate data about the cost of operating each sport program. ABC also provides an enhanced understanding of some aspects of gender equity and Title IX compliance. For athletic directors, university presidents, scholars, and the public to better understand the financial state of intercollegiate athletics, a consistent set of accounting practices needs to be established allowing for comparability between institutions. The COVID-19 global pandemic and resultant economic contraction will demand higher education and intercollegiate athletics innovate like never before in history. In the midst of such a period of innovation, ABC emerges as an accounting method worthy of consideration.

\section{References}

Alesia, M. (2006, March 30). Colleges pay, public pays. Indianapolis Star, p. 1 b.

Anderson, G. (2020, April 24). Pandemic hits college sports. Inside Higher Ed. https://www. insidehighered.com/news/2020/04/24/financial-crisis-related-coronavirus-hits-athleticdepartments

Arnaboldi, M., \& Lapsley, I. (2004). Modern costing innovations and legitimation: A health care study. Abacus, 2, 1-20. https://doi.org/10.1111/j.1467-6281.2004.00143.x

Balakrishnan, R., Labro, E., \& Sivaramakrishnan, K. (2012). Product costs as decision aids: An analysis of alternative approaches (part I). Accounting Horizons, 26(1), 1-20. https://doi. org/10.2308/acch-50086

Bamber, L. S., \& Hughes III, K. E. (2001). Activity-based costing in the service sector: The Buckeye National Bank. Issues in Accounting Education, 8, 381-408. https://doi.org/10.2308/ iace.2001.16.3.381

Banker, R. D., \& Johnston, H. H. (1993). An empirical study of cost drivers in the U.S. airline industry. The Accounting Review, 7, 576-601.

Brown, R. E., Myring, M. J., \& Gard, C. G. (1999). Activity-based costing in government: Possibilities and pitfalls. Public Budgeting \& Finance, 3, 3-21. https://doi.org/10.1046/j.02751100.1999.01160.x

Cardinaels, E., Roodhooft, F., \& Warlop, L. (2004). The value of activity-based costing in competitive pricing decisions. Journal of Management Accounting Research, 16, 133-148. https://doi. org/10.2308/jmar.2004.16.1.133

Carducci, R., Kisker, C. B., Chang, J., \& Schirmer, J. (2007). Answering the call for accountability: An activity and cost analysis case study. Community College Journal of Research and Practice, 31, 1-17. https://doi.org/10.1080/10668920600840665

Clements, R. (2015, April 23). UAB was "ill-advised" to cut football, independent study says. Sporting News. http://www.sportingnews.com/ncaa-football/story/2015-04-23/uab-blazersalabama-birmingham-football-independent-study-ill-advised-cut

Cooper, R., \& Kaplan, R. S. (1988). Measure costs right: Make the right decisions. Harvard Business Review, 5, 96-103.

Dimitropoulos, P. (2007). Activity-based costing in sport organizations: Theoretical background \& future prospects. Sport Management International Journal (Choregia), 3(2), 17-25.

https://doi.org/10.4127/ch.2007.3.2.15-24 
Dinich, H., \& Schlabach, M. (2020, April 22). Schools ask NCAA to relax member requirements. ESPN. https://www.espn.com/college-sports/story//id/29083340/schools-ask-ncaa-relaxmember-requirements

Friga, P. N. (2020, March 24). The great recession was bad for higher education. Coronavirus could be worse. Chronicle of Higher Education. https://www.chronicle.com/article/The-GreatRecession-Was-Bad/248317

Fulks, D. L. (2017). Revenues and expenses of NCAA division I intercollegiate athletics programs: 2004-2016. National Collegiate Athletic Association. http://www.ncaa.org/sites/default/ files/2017RES D1-RevExp_Entire_2017 Final 20180123.pdf

Goff, B. (2000). Effects of university athletics on the university: A review and extension of empirical assessment. Journal of Sport Management, 14, 85-104. https://doi.org/10.1123/jsm.14.2.85

Granof, M. H., Platt, D. E., \& Vaysman, I. (2000). Using activity-based costing to manage more efficiently. The PricewaterhouseCoopers Endowment for the Business of Government.

Graves, W. (2013, December 21). Colleges are cutting sports teams in smaller athletic programs as costs rise. Huffington Post. http://www.huffingtonpost.com/2013/12/21/colleges-cuttingsports_n_4486419.html

Hodge, F., \& Tanlu, L. (2009). Finances and college athletics. In J. Hoffman, J. S. Antony, \& D. D. Alfaro, (Eds.), Data-driven decision making in intercollegiate athletics (pp. 7-18). Jossey-Bass. https://doi.org/10.1002/ir.309

House Resolution 275, 114th Cong. (2015). To establish a commission to identify and examine issues of national concern related to the conduct of intercollegiate athletics, to make recommendations for the resolution of the issues, and for other purposes. https://www.congress.gov/ bill/114th-congress/house-bill/275

Howell, J., \& Rascher, D. (2011). An analysis and assessment of intercollegiate athletics at the University of San Francisco. University of San Francisco (Unpublished).

Jensen, M. (2020, March 27). College sports will be hit hard, and will not be the same economically after the coronavirus. The Philadelphia Inquirer. https://www.inquirer.com/health/coronavirus/coronavirus-covid-19-college-sports-economic-impact-20200327.html

Jorgensen, S., \& Edwards, M. (1998). Activity-based costing in pharmaceutical development. Drug Development Research, 43, 164-173. https://onlinelibrary.wiley.com/doi/ abs $/ 10.1002 / \% 28$ SICI $\% 291098-2299 \% 28199803 \% 2943 \% 3 \mathrm{~A} 3 \% 3 \mathrm{C} 164 \% 3 \mathrm{~A} \% 3 \mathrm{AAID}-$ DDR6\%3E3.0.CO\%3B2-H

Kirk, J. (2014, June 6). College athletic departments aren't necessarily as broke as you think. $S B$ Nation. http://www.sbnation.com/college-football/2014/6/6/5783394/college-sports-profitsmoney-schools-revenues-subsidies

Knight Commission on Intercollegiate Athletics. (1991). Keeping faith with the student athlete: A new model for intercollegiate athletics. The Knight Commission. https://www.knightcommission.org/wp-content/uploads/2008/10/1991-93 kcia_report.pdf

Knight Commission on Intercollegiate Athletics. (1992). A solid start. The Knight Commission. https://www.knightcommission.org/wp-content/uploads/2008/10/1991-93 kcia report.pdf

Knight Commission on Intercollegiate Athletics. (1993). A new beginning for a new century. The Knight Commission. https:/www.knightcommission.org/wp-content/uploads/2008/10/1991-93_kcia_report.pdf

Knight Commission on Intercollegiate Athletics. (2001). A call to action: Reconnecting college sports and higher education. The Knight Commission. https://www.knightcommission.org/ wp-content/uploads/2008/10/2001_knight_report.pdf 
Knight Commission on Intercollegiate Athletics. (2010). Restoring the balance: Dollars, values, and the future of college sports. The Knight Commission. https://www.knightcommission.org/ wp-content/uploads/2017/09/restoring-the-balance-0610-01.pdf

Knight Commission on Intercollegiate Athletics. (2014, July 9). Knight commission call for financial transparency cited by senate committee [Press release]. http://www.knightcommission. org/fiscal-integrity/fiscal-integrity-news/887-july-9-2014-knight-commission-call-for-financial-transparency-cited-by-senate-committee

Lawrence, H. J., Gabriel, E. A., \& Tuttle, L. E. (2010). Leveling the playing field: Creating transparency and consistency in accounting for Division I college athletics. Journal of Intercollegiate Sport, 3, 366-381. https://doi.org/10.1123/jis.3.2.366

LEAD1 Association \& Teamworks. (2020). State of athletics in the face of coronavirus. https:// leadlassociation.com/wp-content/uploads/2020/04/LEAD1.TW-COVID-19-Impact-eBookFINAL.pdf

Major, M., \& Hopper, T. (2005). Managers divided: Implementing ABC in a Portuguese telecommunications company. Management Accounting Research, 6, 205-229. https://doi.org/10.1016/j. mar.2005.01.004

Marsh, J. P., Petersen, J. C., \& Osborne, B. (2016). Sport discontinuation: An assessment of goal achievement via empirical measures. Journal of Amateur Sport, 2(1), 164-187. https://doi. org/10.17161/jas.v2i1.5011

Matheson, V. A., O’Connor, D. J., \& Herberger, J. H. (2012). The bottom line: Accounting for revenues and expenditures in intercollegiate athletics. International Journal of Sport Finance, $7(1), 30-45$.

McCollough, B., \& Fenno, N. (2020, February 7). White House could join NCAA search for solution for name, image, likeness issue. Los Angeles Times. https://www.latimes.com/sports/ story/2020-02-07/ncaa-name-image-license-white-house

McEvoy, C. D., Morse, A. L., \& Shapiro, S. L. (2013). Factors influencing collegiate athletic department revenues. Journal of Issues in Intercollegiate Athletics. 6, 249-267.

NCAA. (n.d.). Title IX frequently asked questions. National Collegiate Athletic Association. http:// www.ncaa.org/about/resources/inclusion/title-ix-frequently-asked-questions

NCAA. (2014). Division I steering committee on governance: Recommended governance model. National Collegiate Athletic Association. http://www.ncaa.org/sites/default/files/DI\%20Steering $\% 20$ Commitee $\% 20$ on $\% 20$ Gov $\% 20$ Proposed $\% 20$ Model $\% 2007 \% 2018 \% 2014 \% 204$.pdf

NCAA. (2018). Agreed-upon procedures. National Collegiate Athletic Association. http://www. ncaa.org/sites/default/files/2018NCAAFIN_Agreed_Upon_Procedures_20180525.pdf

NCAA, schools need more financial transparency, bill says. (2014, July 15). Indianapolis Business Journal. http://www.ibj.com/articles/48601-ncaa-schools-need-more-financial-transparencybill-says

Needy, K. L., Nachtmann, H., Roztocki, N., Warner, R. C., \& Bidanda, B. (2003). Implementing activity-based costing systems in small manufacturing firms: A field study. Engineering Management Journal, 15(1), 3-10. https://doi.org/10.1080/10429247.2003.11415190

Olson, E. (2020, May 30). Number of eliminated college sports programs nearing 100. Associated Press. https://apnews.com/1c7202d94f1e4e64353b75920dda9dd3

Rascher, D. A., \& Schwartz, A. D. (2015). The incremental benefits and costs of football, bowling, and rifle at the University of Alabama at Birmingham. OSKR. http://oskr.com/oskr/wp-content/ uploads/2015/04/uab-part-1.pdf 
Reisch, J. T., \& Seese, L. P. (2005). Compliance with Title IX at Kingston State University: A case study on cost allocation and ethical decision making. Issues in Accounting Education, 20(1), 81-97. https://doi.org/10.2308/iace.2005.20.1.81

Scarborough, A. (2015, June 1). UAB reinstates football for 2016. ESPN.com. http://espn.go.com/ college-football/story/_id/12991674/uab-blazers-football-return

Smith, J., Burt, I., \& Gentile, M. (2019). The role of activity based accounting in athletic departments: Theory, research questions, and an empirical test. The BRC Academy Journal of Business, 9(1), 1-32. https://doi.org/10.15239/j.brcacadjb.2019.09.01.ja01

Sperber, M. (2000). Beer and circus: How big-time college sports is crippling undergraduate education. Henry Holt and Company.

Standardization of Collegiate Oversight of Revenues and Expenditures Act, H.R. 5100, 113th Cong. (2014). https://www.congress.gov/bill/113th-congress/house-bill/5100/.

Stratton, W. O., Desroches, D., Lawson, R., \& Hatch, T. (2009). Activity-based costing: Is it still relevant? Management Accounting Quarterly, 10(3), 31-40.

Talty, J. (2015, May 15). UAB report reveals cost to reinstate football; decision now rest with Ray Watts. AL.com. http://www.al.com/sports/index.ssf/2015/05/uab_report_reveals_how_much it.html

Tatos, T. (2019). An empirical evaluation of EADA and NCAA college sports financial data: Applications for research and litigation. Marquette Sports Law Review, 29(2). https://scholarship. law.marquette.edu/sportslaw/vol29/iss $2 / 5 /$

The Drake Group. (2015). Position statement: Establishment of a presidential commission on intercollegiate athletics reform. https://drakegroupblog.files.wordpress.com/2015/03/presidential-commission-position-paper.pdf/

Thelin, J. R. (2000). Good sports. The Journal of Higher Education, 71(4), 391-410. https://doi.org/ $\underline{10.1080 / 00221546.2000 .11778842}$

Tuttle, L. E. (2009). Leveling the playing field: Creating transparency and consistency in accounting for Division I college athletics (Undergraduate honors tutorial culminating research, Ohio University).

U.S. Department of Education. (n.d.). The equity in athletics data analysis cutting tool. http://ope. ed.gov/athletics

U.S. Department of Education Office for Civil Rights. (2005). Requirements under Title IX of the Education Amendments of 1972. http://www2.ed.gov/about/offices/list/ocr/docs/interath.html

Zeller, T. L. (2000). Measuring and managing e-retailing with activity-based costing. Journal of Cost Management, 1, 17-30.

Zimbalist, A. (2003). What to do about Title IX. Gender Issues, 21(2), 55-59. https://doi. org/10.1007/s12147-003-0016-x 